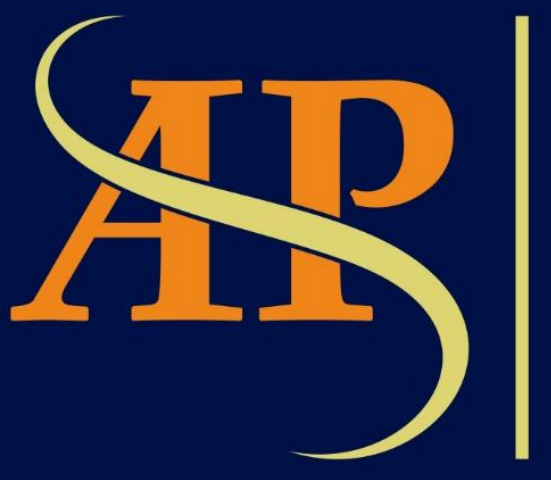

JURNAL

ASIA

PACIFIC

STUDIES

Journal of International Relations Study Program Faculty of Social and Political Sciences Universitas Kristen Indonesia

Volume I | Number 1 | January- June 2017 


\title{
PENETAPAN ALUR LAUT KEPULAUAN INDONESIA (ALKI): MANFAATNYA DAN ANCAMAN BAGI KEAMANAN PELAYARAN DI WILAYAH PERAIRAN INDONESIA
}

\author{
Siti Merida Hutagalung \\ Hubungan Internasional, Fakultas Ilmu Sosial dan Ilmu Politik, Universitas Kristen Indonesia, \\ Jl. Mayjen. Sutoyo No. 2, Cawang, Jakarta Timur 13630, Indonesia \\ meridasiti@yahoo.co.id
}

\begin{abstract}
Indonesia is the largest archipelago after the United States with 13,465 islands, total land area $1.922 .570 \mathrm{~km}^{2}$ and total water area 3,257,483 $\mathrm{km}^{2}$. As a country that has ratified the International Sea Law Convention, there are legal obligations and responsibilities to grant the rights of innocent, archipelagic sea lanes and transit passages for foreign ships and foreign aircrafts to sail and fly in the territory of Indonesian sovereignty as stipulated in Article 51 of the International Sea Law Convention 1982. Foreign ships and aircraft may pass through the territorial and waters of the Indonesian archipelago through specific sections and routes undertaken by determining archipelagic sea lanes. In 2002, through a long process, the concept of ALKI proposed by Indonesia finally got approval from Malaysia, Singapore, Philippines, including Organization Maritime International. The three Archipelagic Sea Lanes of Indonesia (ALKI) is called ALKI I, ALKI II and ALKI III. The determination of this archipelago path provides benefits and threats to the safety of shipping along the territorial waters of Indonesia. Therefore, the government set various conditions to cross the ALKI in order to provide a sense of security for foreign ships and foreign aircraft sailing along the archipelagic sea lanes. Each archipelagic sea lane has different benefits and challenges depending on the geopolitical and geographic conditions of them. The type of research used in this paper is qualitative research with descriptive analysis approach.
\end{abstract}

Keywords: ALKI, Archipelago, Safety

\begin{abstract}
Abstrak
Indonesia adalah negara kepulauan terbesar setelah Amerika Serikat dengan jumlah 13.465 pulau, luas daratan $1.922 .570 \mathrm{~km}^{2}$ dan luas perairan $3.257 .483 \mathrm{~km}^{2}$. Sebagai negara yang telah meratifikasi Konvensi Hukum Laut Internasional ada kewajiban dan tanggung jawab hukum untuk memberikan hak lintas damai, hak lintas alur laut kepulauan dan hak lintas transit bagi kapal-kapal asing dan pesawat udara asing untuk berlayar dan terbang di wilayah kedaulatan Indonesia sebagaimana diatur dalam pasal 51 Konvensi Hukum Laut Internasional 1982. Kapal-kapal dan pesawat asing dapat melintasi wilayah teritorial dan perairan kepulauan Indonesia melalui bagian dan rute tertentu yang dilakukan dengan cara menentukan alur laut kepulauan. Pada tahun 2002 melalui proses yang panjang konsep ALKI yang diusulkan Indonesia akhirnya mendapat persetujuan dari negara-negara Malaysia, Singapura, Filipina termasuk Organization Maritime International. Ketiga Alur Laut Kepulauan Indonesia (ALKI) disebut dengan ALKI I, ALKI II dan ALKI III. Penentuan alur kepulauan ini memberikan manfaat dan ancaman bagi keamanan pelayaran di sepanjang wilayah perairan Indonesia. Oleh sebab itu, pemerintah menetapkan berbagai syarat untuk dapat melintasi ALKI agar memberikan rasa aman bagi kapalkapal asing dan pesawat udara asing yang berlayar di sepanjang alur laut kepulauan. Setiap alur laut kepulauan mempunyai manfaat dan tantangan yang berbeda-beda tergantung kondisi geopolitik dan geografis dari setiap alur laut kepulauan. Jenis penelitian yang digunakan dalam tulisan ini adalah penelitian kualitatif dengan pendekatan analisis deskriptif.
\end{abstract}

Kata Kunci: ALKI, Negara Kepulauan, Keselamatan 


\section{Pendahuluan}

Melalui perjuangan yang cukup panjang dan alot pada akhirnya masyarakat internasional dapat mengatasi perbedaan pendapat di antara negara-negara peserta dengan disepakatinya Konvensi Hukum Laut Internasional 1983, yang biasa disebut dengan UNCLOS 1983. Hukum Laut Internasional dapat dimaknai sebagai instrumen internasional yang melindungi kepentingan nasional di wilayah perairan seperti perbatasan di darat, laut dan udara yang diakui oleh dunia internasional. Indonesia merupakan salah satu negara yang diuntungkan dalam Konvensi Hukum Laut Internasional III tahun 1982. Wilayah laut Indonesia, termasuk dasar laut dan tanah di bawahnya serta wilayah udara, menjadi berlipat ganda. Luasnya dari $10.000 \mathrm{~km}^{2}$ menjadi kira-kira $3.000 .000 \mathrm{~km}^{2}$, sedangkan wilayah udara bertambah dari kira-kira $2.000 .000 \mathrm{~km}^{2}$ (termasuk di atas darat) menjadi kira-kira 5.000.000 $\mathrm{km}^{2}$. Sementara itu, kewenangan mengelola kekayaan alam di Zona Ekonomi Eksklusif (ZEE) dan Landas Kontinen bertambah kira-kira $3.000 .000 \mathrm{~km}^{2}$, sehingga laut yang menjadi kewenangan Indonesia kira-kira $6.000 .000 \mathrm{~km}^{2}$.

Dengan luas wilayah yang begitu besar di darat, udara maupun laut, Indonesia mempunyai tanggung jawab yang besar untuk mengelola dan mengawasi wilayah lautnya. Potensi wilayah perairan yang begitu strategis secara geopolitik, geografis ditambah dengan posisi silang Indonesia yang diapit dua benua, Asia dan Australia, serta terletak di antara Samudera Pasifik dan Samudera Hindia membuat Indonesia menjadi negara yang sangat strategis dan diperhitungkan banyak negara lainnya. Konsekuensinya, Indonesia juga mempunyai tugas dan tanggung jawab dalam melindungi kedaulatan wilayah perairannya. Hal ini senada dengan yang dikemukakan oleh Bynkershoek bahwa semua negara yang memiliki wilayah laut sangat tergantung kepada kemampuan negara tersebut untuk melakukan pengawasan terhadap wilayah laut yang dikuasainya (Kusumaatmadja 1978, 15). Selain itu, sebagai negara kepulauan Indonesia berbatasan laut dengan Malaysia, Singapura, Filipina, Papua New Guinea, Timor Leste, Australia, India, Thailand, Vietnam dan Palau. Keadaan ini membuat Indonesia rawan dengan konflik perbatasan.

Disisi lain, dalam menjalankan tugas dan fungsi kedaulatannya di perairan, Indonesia harus memperhatikan kepentingan masyarakat internasional dalam menggunakan perlintasan laut, yaitu lintas damai, lintas alur laut kepulauan dan lintas transit. Hal ini senada dengan pasal 51 Konvensi Hukum Laut 1982 agar negara kepulauan menghormati negara tetangga jika melintas di perairan kepulauan. Dalam rangka menindaklanjuti pasal 51 Konvensi Hukum Laut 1982, pemerintah telah mengeluarkan berbagai peraturan di bidang kelautan yaitu UU No. 6 Tahun 1996 tentang Perairan Indonesia, Peraturan Pemerintah No. 37 Tahun 2002 tentang Peraturan Pemerintah No. 37 Tahun 2002 tentang Hak dan Kewajiban Kapal dan Pesawat Udara Asing dalam Melaksanakan Hak Lintas Alur Kepulauan. Akses kepada kapal dan pesawat udara Malaysia, hak lintas akses dan komunikasi hasil kerja sama bilateral dituangkan dalam UU No. 1 Tahun 1983. Ketentuan ini dibuat sebagai bentuk kewajiban kepada masyarakat internasional yang dilakukan oleh negara kepulauan, walaupun dalam penentuan alur dan lintas kepulauan akan banyak menimbulkan banyak kesulitan karena bersinggungan dengan kepentingan banyak negara. Penetapan alur kepulauan sebagai rezim baru untuk pelaksanaan pelayaran dan penerbangan internasional wajib dilaksanakan sebagaimana diatur Konvensi Hukum Laut 1982. Hal ini disebabkan ketiadaan ketentuan di dalam hukum internasional tentang pengaturan lintas ini sebelumnya (Djalal 2010).

\subsection{Permasalahan}


Negara Indonesia adalah negara kepulauan pertama yang berhasil menetapkan 3 (tiga) Alur Laut Kepulauan Indonesia (ALKI). Penentuan ALKI dilakukan dengan cara menafsirkan ketentuan Konvensi Hukum Laut 1982 dan mengadakan serangkaian pertemuan dengan beberapa negara seperti Malasyia, Sinagapura, Filipina, Amerika Serikat, Australia, Inggris, Jepang serta melibatkan International Maritime Organization (IMO) dan International Hydrographic Organization (IHO). Dengan penetapan ALKI, muncul banyak persoalan terutama mengenai ancaman keselamatan dan keamanan pelayaran di sepanjang alur laut kepulauan. Tentunya hal ini berkaitan dengan pengawasan dan pengendalian di sepanjang alur laut kepulauan yang sudah menjadi perairan internasional.

\subsection{Tujuan Penulisan}

Implementasi ALKI I, ALKI II, ALKI III memberikan pengaruh terhadap keselamatan keamanan kapal yang melintasi alur tersebut karena menjadi wilayah terbuka dan ada ruterute yang harus dilalui. Hal ini memberikan pekerjaan baru bagi Indonesia untuk melindungi dan menjaga keselamatan pengguna alur laut kepulauan. Tulisan ini bertujuan untuk mengkaji pengaruh alur laut kepulauan terhadap keselamatan dan keamanan kapal-kapal asing dan pesawat asing yang melintas di sepanjang alur laut kepulauan.

\subsection{Metodologi}

Metodologi yang digunakan dalam tulisan ini adalah penelitian kualitatif dengan pendekatan deskriptif analisis. Pengumpulan data lebih banyak menggunakan data sekunder dari buku-buku, peraturan perundang-undangan, jurnal, berita-berita di surat kabar, media elektronik, hasil penelitian dan hasil-hasil seminar atau diskusi yang membahas mengenai alur laut kepulauan. Sumber data diperoleh dari perpustakaan kementerian kelautan, kantor TNI Angkatan Laut dan lain-lain. Data tersebut dihimpun dan dianalisis dengan menggunakan pendekatan kualitatif. Tulisan ini juga menggunakan situs web yang memberitakan tentang alur laut kepulauan.

\subsection{Kajian Pustaka dan Kerangka Pemikiran}

Letak geografis Indonesia yang bertumpu di antara dua benua (Asia dan Australia) dan dua samudera Indonesia (Samudera Hindia dan Samudera Pasifik) membuat Indonesia menjadi negara yang berperan penting menyangkut kepentingan banyak negara di bidang maritim. Dalam teori geopolitik yang berfokus pada paham determenisme, letak geografis suatu negara dapat menentukan kehidupannya baik secara politik (kekuasaan), ekonomi, budaya ataupun teknologi yang dihasilkan oleh negara tersebut (Suprianto 2014, 45) .

Wilayah kedaulatan Indonesia yang terdiri atas $80 \%$ perairan dan dikelilingi banyak pulau membuat Indonesia menjadi negara kepulauan terbesar dan hal ini dapat dijadikan sebagai modal dasar dalam pembangunan ekonomi, sosial, politik dan keamanan maritim. Prinsip fundamental kedaulatan negara di laut teritorial antara lain: "Kedaulatan suatu negara pantai selain wilayah darat dan perairan pedalamannya dan dalam hal suatu negara kepulauan, perairan kepulauannya, meliputi pula suatu jalur laut yang berbatasan dengannya dinamakan laut teritorial"' (pasal 2).

Pemahaman dan paradigma di bidang kelautan berbeda dahulu dengan sekarang dan mengalami perkembangan dari waktu ke waktu. Dalam hukum laut internasional tradisional dikenal 'laut bebas tidak ada yang memiliki.' Paham ini dikembangkan Gracius dan berkembang di Belanda. Di Inggris diprakarsai J. Seldom yang mengatakan bahwa negara 
memiki kedaulatan terbatas atau res nullus. Pada waktu itu lebih banyak dibahas wilayah daratan yang terdiri dari pulau-pulau ataupun karang, yang berorientasi pada kedaulatan di darat daripada kedaulatan di laut. Bersamaan dengan perkembangan teknologi kelautan, terjadi perubahan terhadap paradigma kelautan. Laut dipandang dapat menjamin kebutuhan umat manusia. Lahirlah konsep-konsep kelautan di antaranya konsep negara kepulauan, "memandang perairan yang berada di sekitar pulau-pulau merupakan bagian integral dari pulau darat; artinya tercipta hubungan yang integralistik antara manusia, pulau, perairan dan sumber daya alam yang di dalamnya."

Konsep wawasan nusantara sebagai cara pandang bangsa dan wilayah Indonesia sebagai bagian yang tidak terpisahkan dikumandangkan pertama sekali pada Hari Sumpah Pemuda tahun 1920, kemudian pada hari proklamasi tanggal 17 Agustus 1945. Kemudian dilanjutkan dengan pengumuman Perdana Menteri Djuanda yang disebut dengan Deklarasi Djuanda pada tanggal 13 Desember 1959 dengan istilah dan gagasan Indonesia sebagai negara kepulauan. Isinya, “...berdasarkan pertimbangan, maka pemerintah Indonesia menyatakan segala perairan di sekitar, di antara dan yang menghubungkan pulau-pulau termasuk negara Indonesia dengan tidak memandang luas atau lebarnya adalah bagian-bagian yang wajar daripada wilayah daratan Negara Kesatuan Republik Indonesia." Kemudian diundangkan dalam UU No. 4 Prp Tahun 1960 Tentang Perairan Indonesia dalam pasal 4 menetapkan bahwa negara Republik Indonesia di perairan Indonesia meliputi laut teritorial, perairan kepulauan, dan perairan pedalaman serta ruang udara di atas laut teritoral, perairan kepulauan, dan perairan pedalaman serta dasar laut dan tanah di bawahnya termasuk sumber kekayaan dan yang terkandung di dalamnya.

Berbeda pada masa kolonial Hindia Belanda, konsepsi perairan pada waktu itu didasarkan pada Territoriale Zee en Maritieme Krigen Ordonantie 1939 dan lebar laut wilayah sepanjang 3 mil. Penarikannya dengan menggunakan sistem normal atau base line. Sedangkan menurut Konvensi Hukum Laut 1982, lebar laut kepulauan ditentukan dengan menggunakan sistem Archipelagic Straight Base Line dan luas wilayah perairan menjadi sepanjang 12 mil. Hasil dari konsep negara kepulauan melahirkan kesatuan wawasan nusantara yang berarti seluruh perairan antara dan yang mengelilingi pulau-pulau Indonesia dinyatakan sebagai wilayah Republik Indonesia, dan laut wilayah Indonesia menjadi 12 mil diukur dari garis-garis dasar yang mengelilingi seluruh wilayah nusantara; bukan dari garis pantai setiap pulau.

Ahli maritim Prescott menyatakan ketika suatu negara mendeklarasikan diri sebagai negara kepulauan, maka negara itu mempunyai tanggung jawab besar kepada masyarakat internasional untuk menyediakan hak lintas alur laut kepulauan di perairan kepulauan dan laut teritorial (Prescott dan Schofield 2005, 45). Hampir sama dengan Prescott, ahli hukum laut Indonesia, Hasyim Djalal, berpendapat bahwa keberhasilan penerimaan konsep negara kepulauan sebagai suatu prinsip hukum mengandung konsekuensi timbal balik. Dalam hal ini adalah hak lintas yang melebihi dari hak lintas damai.

Konsep negara kepulauan menurut Indonesia adalah hubungan yang integralistik antara manusia, wilayah yang terdiri dari pulau, perairan serta sumber daya alam yang ada di dalamnya sebagai entitas tunggal (Wisnumurti 2007, 392-393). Hubungan integralistik antara bentuk geografis dalam aspek ekonomi, sosial-budaya dan politik sangat penting dalam negara kepulauan. Konsep kepulauan (archipelagic) dalam pasal 46 Konvensi Hukum Laut 1982 diartikan sebagai “... suatu gugusan pulau, temasuk bagian pulau, perairan di antaranya dan lain-lain wujud alamiah yang hubungannya satu sama lain demikian eratnya sehingga pulau-pulau, perairan dan wujud alamiah lainnya merupakan satu kesatuan geografis, ekonomi, politik yang hakiki, atau yang secara historis dianggap demikian." Konsep kepulauan mengandung makna sangat luas dan membuat negara menjadi terintegrasi secara geografis, ekonomi, sosial, politik dan keamanan. 
Kelemahan dari pasal 46 Konvensi Hukum Laut 1982 ialah tidak menjelaskan kriteria penentuan negara kepulauan dan ini menimbulkan masalah bagi negara dalam menentukan klaim yurisdiksinya menjadi tidak sama. Sehingga dalam penarikan garis pangkal kepulauan menimbulkan kesulitan; pertama, penghitungan rasio antara luas perairan/laut dengan daratan panjang garis pangkal dan penjelasan tentang konfigurasi umum kepulauan. Kedua, sistem garis pangkal kepulauan akan menempatkan selat di bawah yuridiksi suatu negara tertentu yang dapat mengganggu perairan internasional, jika negara tersebut tidak dapat melaksanakan hak dan kewajibannya sebagaimana mestinya. Selain itu, masih kurang jelasnya pengaturan tentang aktivitas militer, pengaturan ruang udara di atas alur alut kepulauan, operasionalisasi keamanan, keselamatan di laut dan wahana laut, serta para pekerja di laut. Hal ini menyebabkan terjadinya insiden Bawean pada tahun 2003. Saat ini diperlukan persamaan pemahaman operasional kapal di alur laut dan udara. Kedaulatan yang dimiliki negara kepulauan meliputi seluruh daratan, perairan pedalaman, perairan kepulauan, laut teritorial termasuk ruang udara di atasnya, dasar laut dan tanah di bawahnya serta sumber daya alam di dalamnya (Konvensi Hukum Laut Internasional 1982, pasal 2 dan 49 ayat 2).

Dalam menjalankan kedudukan sebagai negara kepulauan, Indonesia harus memperhatikan kepentingan masyarakat internasional di bidang pelayaran dan penerbangan asing bagi kapal-kapal asing yang melintasi perairan kepulauan seperti hak lintas damai, hak lintas alur laut kepulauan, hak lintas transit dan hak lintas akses komunikasi. Hak-hak tersebut dijamin oleh UU No. 6 Tahun 1996 sebagai implementasi dari Hukum Laut Internasional 1982 yang mengandung arti bahwa negara kepulauan harus menghormati hak negara lain dan hak negara pengguna harus mendapat perhatian juga. UU No. 6 Tahun 1996 mengakui beberapa hak; misalnya, pengakuan terhadap hak-hak perikanan tradisional dan hak pelayaran di perairan kepulauan sehingga tercipta harmonisasi antara negara kepulauan dengan negara pengguna.

Kewajiban dan tanggung jawab lainnya ditetapkan dalam Konvensi Hukum Laut Internasional 1983 yang diberikan kepada negara kepulauan; berhubungan dengan hak dan kebebasan pelayaran, kedaulatan perairan, serta pulau dan bentuk geografis yang dihubungkan. Negara pengguna maritim mendapat hak lintas pelayaran bagi kapal dan pesawat udara melalui dan di atas perairan kepulauan dan laut teritorial di hadapannya, sebagai titik masuk dan/atau keluar yang disebut dengan 'hak lintas damai' atau 'hak lintas alur kepulauan'. Hak lintas alur kepulauan sama dengan lintas transit melalui selat dalam pelayaran internasional. Pasal 53 ayat 3 Konvensi Hukum Laut III 1982 menentukan hak lintas alur laut kepulauan, yaitu "....hak pelayaran dan penerbangan dengan normal mode yang hanya digunakan untuk lintas terus-menerus, langsung dan tidak terhalangi dari satu bagian ZEE dan laut bebas ke bagian lain ZEE dan laut bebas.”

Dari ketentuan pasal 53 ayat 3, menurut Kresna Buntoro, ALKI mengandung lima hal yaitu: pertama, hak negara kepulauan untuk menentukan ada atau tidaknya alur laut kepulauan. Kedua, tidak ada rute udara tanpa rute laut di bawahnya. Ketiga, alur laut harus cocok untuk lintas. Keempat, lintas harus-terus menerus dan langsung. Kelima, lintas untuk kapal dan pesawat udara asing (Buntoro 2012, 92).

Secara normatif tidak ada keharusan bagi negara kepulauan untuk menentukan ada atau tidaknya alur negara kepulauan, sehingga tidak ada kewajiban untuk mengadakannya. Namun, dengan pengkajian yang cukup mendalam disertai dengan pertimbangan yang salah satu diantaranya adalah jika alur laut kepulauan tidak ditetapkan, maka lintas alur laut kepulauan dapat dinikmati oleh kapal dan pesawat udara asing di rute yang biasa digunakan untuk pelayaran internasional. Rute pelayaran internasional bagi negara kepulauan menimbulkan masalah karena pengertian "rute yang biasa digunakan untuk pelayaran internasional" masih kurang jelas, sehingga dapat menimbulkan implementasi yang bermacam-macam. Begitu juga halnya dengan pemahaman kapal dan pesawat udara dapat 
melintas secara bebas, dapat juga dimaknai sebagai lintas pergerakan kekuatan militer dari satu tempat ke tempat yang dituju atau dapat dijadikan untuk memfasilitasi kepentingan atau kebutuhan kekuatan militer. Kekhawatiran tersebut bisa terjadi walaupun belum terdapat bukti-bukti alur laut kepulauan ditujukan untuk kepentingan pergerakan kekuatan militer.

Hasyim Djalal berpendapat, hak lintas alur laut kepulauan pada dasarnya ditujukan untuk navigasi bagi kapal; termasuk kapal selam dan kebebasan penerbangan pesawat udara. Hak lintas damai dapat diartikan sebagai kegiatan navigasi komersial melalui perairan kepulauan $(2012$, 56). Ketiadaan hak lintas damai untuk penerbangan pesawat udara tidak membatasi penerbangan sipil. Yurisdiksi dimiliki negara kepulauan terhadap seluruh daratan/pulau, perairan, pedalaman, perairan kepulauan, laut teritorial termasuk ruang udara di atasnya, laut dan tanah di bawahnya serta sumber daya alam di dalamnya. Sebagai rezim baru dalam hukum internasional, karakteristik negara kepulauan dielaborasi sebagai berikut menurut Churchill dan Lowe: such waters are neither international waters nor territorial sea, although they bear a number of resemblance to the latter (Ibid.) Lebih lanjut dikatakan Churcill dan Lowe, perairan kepulauan tidak sama dengan perairan pedalaman dan laut teritorial, akan tetapi apabila dilihat dalam konteks hak dan kewajiban negara lain di perairan dan laut yang dimaksud, maka perairan kepulauan identik dengan laut teritorial (Buntoro 2012, 24).

\section{Hasil dan Pembahasan}

Ketika suatu negara sudah memberikan sebagian wilayah perairan teritorial menjadi terbuka untuk pelayaran internasional, maka negara tersebut sudah melaksanakan kewajibannya sebagai negara kepulauan yang disertai dengan pemberian hak-hak navigasi bagi kapal asing dan pesawat asing. Hak navigasi yaitu hak negara-negara asing untuk bebas berlayar di sepanjang perairan internasional dan mendapat perlindungan kemanan di sepanjang ALKI I, ALKI II dan ALKI III dari negara kepulauan. Setiap negara kepulauan mempunyai hak lintas damai, hak lintas alur kepulauan dan hak lintas transit dengan menggunakan skema pemisah. Penetapan Alur Lintas Kepulauan Indonesia menimbulkan manfaat sekaligus menjadi tantangan bagi kedaulatan negara kepulauan. Dengan perubahan dari wilayah tertutup menjadi wilayah terbuka bagi pelayaran internasional menyebabkan muncul isu-isu yang berhubungan dengan keselamatan dan keamanan pelayaran di sepanjang alur laut kepulauan.

\subsection{Negara Kepulauan dan Navigasi}

Julukan sebagai negara kepulauan memberikan pengaruh dan tuntutan yang besar bagi Indonesia dalam hal navigasi oleh masyarakat internasional. Kebutuhan navigasi yang menyangkut hak kebebasan pelayaran selalu menjadi hal menarik untuk dibahas dalam pertemuan-pertemuan dengan negara-negara kepulauan. Hak navigasi diberikan oleh Konvensi Hukum Laut Internasional 1982 kepada negara kepulauan dan negara pengguna terdiri dari hak lintas damai, hak lintas alur kepulauan dan hak lintas transit. Ketiga hak itu sudah dikenal sejak lama dan negara kepulauan menjamin adanya hak lintas damai, walaupun telah ditetapkan alur kepulauan.

Dalam menentukan hak lintas dapat dilakukan dengan menetapkan alur laut dan skema pemisah lalu lintas laut (sea-lanes and traffic separation schemes) untuk menjamin keselamatan jalur pelayaran. Hak lintas damai ditentukan di rute-rute normal yang biasa digunakan di rute-rute pelayaran normal dan sering kali digunakan dalam pelayaran internasional maupun nasional. Kapal asing yang menggunakan hak lintas damai harus 
mengikuti sejumlah syarat, yaitu kewajiban kapal untuk mematuhi peraturan perundangundangan negara yang dilewati, mematuhi Alur Laut dan Skema Pemisah Lalu Lintas (Traffic Separation Scheme/TSS), dan membayar layanan khusus. Ada pengecualian untuk kapal perang yang menggunakan lintas damai, yakni harus memenuhi persyaratan seperti nofikasi/pemberitahuan terlebih dahulu atau otoritasi untuk pertimbangan kedaulatan dan keamanan nasionalnya.

Keharusan untuk menyediakan lintas damai pada alur laut kepulauan menimbulkan kesulitan untuk membedakan lintas kepulauan dan lintas damai karena rute lintas damai sama dengan rute alur laut kepulauan. Untuk mengatasinya, perlu diadakan perbedaan dalam menjalankan hak lintas damai dengan hak lintas alur kepulauan. Oleh karena itu, menurut Hasym Djalal sangat penting dibuat perbedaan; misalnya dalam lintas damai kapal selam dan wahana bawah laut disyaratkan agar bernavigasi di permukaan laut dan menunjukkan bendera. Untuk lintas alur laut kepulauan diperbolehkan bernavigasi secara normal dan ada kemungkinan lintas kapal/wahana di bawah/dalam air. Dalam lintas damai tidak ada hak penerbangan dan dapat ditangguhkan; berbeda dengan lintas alur kepulauan yang mempunyai hak penerbangan melalui rute udara di atas laut dan tidak dapat ditangguhkan. Untuk pengawasan dan kontrol diberikan berlebih pada negara kepulauan, sedangkan untuk alur laut kepulauan sifatnya lebih terbatas. Bagi kapal perang yang bernavigasi dalam lintas damai masih terdapat pandangan yang berbeda antara harus ada pemberitahuan atau tanpa pemberitahuan karena tidak diatur secara tegas dalam hukum internasional. Hal ini berbeda dengan alur lintas kepulauan di mana setiap kapal perang dan pesawat asing bebas untuk menggunakan lintas alur laut kepulauan.

Dalam hal penindakan kalau ada kapal asing yang melakukan pelanggaran hukum, sulit untuk menegakkan aturan penggunaan hak lintas damai atau hak lintas alur kepulauan. Karena, dalam satu rute pelayaran terdapat hak lintas damai sekaligus hak lintas alur kepulauan. Perlu ada pemikiran dan keputusan internasional yang dikeluarkan oleh IMO dan negara-negara pengguna laut untuk merumuskan perbedaan antara hak lintas damai dan hak lintas alur laut kepulauan. Dengan demikian dapat terjamin keselamatan dan keamanan di sepanjang perairan negara kepulauan bagi kapal-kapal dan pesawat udara yang melintasi alur laut kepulauan dan lintas damai.

Selain hak lintas damai dan hak alur kepulauan, dikenal juga hak lintas transit. Pengaturan hak lintas transit diatur dalam Konvensi Hukum Laut Internasional 1982 pasal 38 ayat 1, "semua kapal dan pesawat udara menikmati hak lintas." Artinya kapal dan pesawat udara dapat memasuki dan transit dalam suatu negara selat dan menjadi navigasi internasional. Selat sebagai perairan internasional disepakati sejak tahun 1982. Lebar laut teritorial negara kepulauan adalah sepanjang 12 mil laut diukur dari base line. Hal ini berpengaruh pada status selat yang selama ini sebagai laut bebas, berubah menjadi laut teritorial.

Selat merupakan jalur sempit atau bagian perairan yang menghubungkan dua bagian perairan yang lebih besar. Ada beberapa istilah yang digunakan untuk menggambarkan selat seperti terusan (channel), lintasan/jalur ( passage way), belt dan lain-lain. Penambahan lebar laut teritorial menimbulkan pengaruh untuk akses ke selat karena selama ini dapat melintasi secara bebas berlayar (freedom of navigation). Namun dengan adanya perubahan itu, pengguna harus melintasi wilayah kedaulatan suatu negara yang berbatasan dengan selat seperti berlayar, menyelam, terbang yang digunakan dalam pelayaran internasional.

Fungsi selat dalam perkembangannya sangat penting karena berhubungan dengan ekonomi dan militer seperti yang disampaikan oleh Richardson (Buntoro 2014, 148-149). Lebih dari seratus selat di seluruh dunia mempunyai lebih dari enam mil tetapi kurang dari dua puluh empat mil laut. Sepanjang laut teritorial di setiap selat dalam batas tiga mil laut, sebuah rute laut bebas akan mempunyai kebebasan penuh untuk navigasi dan penerbangan. 
Tetapi perpanjangan laut teritorial di kedua sisi dua belas mil laut akan menghilangkan koridor laut bebas ini, sementara negara yang berbatasan bisa menganggap bahwa selat itu tetap tunduk pada hak lintas damai. Hasilnya, ini dapat secara serius mengganggu fleksibilitas pasukan konvensional Amerika Serikat, kapal-kapal selam rudal balistik yang bergantung pada kekuatan, mobilitas, dan fleksibilitas angkatan bersenjata. Kesejahteraan ekonomi Amerika Serikat terus menerus sangat bergantung pada perdagangan luar negeri dan lebih rentan terhadap perkembangan politik luar negeri negara lain. Hasil gabungan adalah memaksa meningkatnya ketergantungan pada kekuatan dan mobilitas fleksibilitas angkatan bersenjata. Pencegahan dan misi perlindungan dari angkatan bersenjata ini membantu mobilitas global. Erosi dari aturan tradisional dan kecenderungan memperluas klaim yuridiksi negara-negara pantai telah semakin meningkatkan risiko tantangan.

Dalam suatu pelayaran, lintas transit dan lintas alur kepulauan dapat digunakan sekaligus. Timbulnya masalah hak lintas damai, hak alur laut kepulauan dan hak transit disebabkan hak alur laut kepulauan di dalamnya mengandung hak lintas damai dan hak lintas transit sehingga sangat sulit memisahkan secara tegas jika suatu negara kepulauan menetapkan lintas alur laut kepulauan. Lahir silang pendapat di kalangan para ahli hukum internasional. Ada yang mengatakan terdapat perbedaan, tetapi ada pula mengatakan sebaliknya, sehingga terdapat perbedaan dalam penerapannya. Hasyim Djalal mengatakan ada perbedaan penerapan lintas transit dengan lintas alur kepulauan sebagaimana yang diatur dalam pasal 38 ayat 2 dengan didasarkan normal made of navigation (Ibid.) Sehingga, ada syarat yang wajib dipatuhi jika melintas di alur laut kepulauan, sedangkan lintas transit dengan pasal 53 Konvensi Hukum Laut Internasional mengacu pada hak melintasi (right of passage). Lintas transit bebas dilakukan kapal dan pesawat udara asing. Semua kapal dan pesawat udara termasuk kapal dagang, kapal perang/tanker, kapal selam, pesawat komersial, pesawat pemerintah yang berjadwal dan tidak berjadwal.

\subsection{ALKI dan Tantangan yang Dihadapi}

Indonesia termasuk dari 117 negara yang telah meratifikasi Konvensi Hukum Laut di Montego-Boy Jamaica tahun 1982 dan kemudian dirumuskan dalam UU Nomor 17 Tahun 1985. Kewajiban Indonesia sebagai bentuk tanggung jawab negara kepulauan kepada masyarakat internasional membuat alur lintas kepulauan. Tujuan ditetapkannya alur laut kepulauan adalah agar kapal-kapal asing dan penerbangan internasional dapat berjalan terusmenerus dan berlangsung dengan cepat tanpa hambatan. ALKI merupakan pedoman atau acuan agar tidak terjadi pelanggaran bagi kapal-kapal asing yang melintasi wilayah perairan Indonesia.

Landasan yang digunakan negara kepulauan dalam merumuskan alur lintas kepulauan adalah pasal 53 ayat 1, yaitu "suatu negara kepulauan dapat menentukan alur laut dan rute penerbangan yang cocok untuk digunakan lintas kapal dan pesawat udara asing yang terus-menerus langsung serta secepat mungkin melalui atau di atas perairannya dan laut teritorial yang berdampingan dengannya." Selain alur kepulauan, negara kepulauan dapat menetapkan skema pemisah lintas untuk keperluan lintas kapal yang aman melalui terusan yang sempit dalam alur laut kepulauan." Dari ketentuan pasal 53 ayat 1 dapat disimpulkan bahwa alur laut kepulauan ditujukan kepada berbagai jenis kapal dan pesawat udara asing. Untuk penerbangan, hanya rute di atas alur laut kepulauan dan dilakukan secara terusmenerus langsung serta secepat mungkin. Selain itu, alur laut kepulauan meliputi juga perairan teritorial yang terdekat dan harus cocok untuk mengadakan lintasan secara langsung dan tidak terputus. 
Sesuai dengan bunyi pasal 53 ayat 1, tidak ada keharusan bagi pemerintah Indonesia untuk membuat alur laut kepulauan dan boleh saja Indonesia tidak menentukannya. Tetapi sebagai konsekuensinya semua kapal internasional diperbolehkan melewati jalur-jalur navigasi yang sudah normal digunakan dalam pelayaran dunia (pasal 53 ayat 12, routes normally used for international navigation). Sehingga kriteria dari alur laut kepulauan harus 'dilakukan terus-menerus, cocok dan tidak terputus-putus atau suitable, aman untuk kapal dari gangguan navigasi (savety of navigation).' Menurut Kresno Buntoro $(2012,51)$, lintas 'terusmenerus' mengandung arti bahwa negara kepulauan dalam menentukan alur laut kepulauan harus mempertimbangkan ZEE dan landas kontinen. Kapal asing dan pesawat udara asing yang melintasi secara terus-menerus dapat memasuki atau berangkat dari pelabuhan negara kepulauan tanpa pemberitahuan sebelumnya.

Dalam penentuan alur laut kepulauan ada faktor-faktor yang harus diperhatikan, yaitu: Pertama, ketentuan Hukum Laut Internasional 1982 dan ketentuan-ketentuan hukum internasional lainnya. Kedua, teknis kelautan yang antara lain meliputi hidrografi, perlindungan lingkungan laut, wilayah pertambangan, kabel pipa dan pipa di bawah laut, wilayah dumping dan pembuangan ranjau, wilayah perikanan. Ketiga, letak alur laut kepulauan. Keempat, berapa banyak jumlah alur laut kepulauan dan lintas alur kepulauan yang telah ditetapkan Indonesia; yaitu ALKI I meliputi jalur lintas perairan Laut Jawa, Selat Karimata, Selat Sunda, Laut Natuna dan Laut Tiongkok Selatan yang menghubungkan lalu lintas perairan dan perdagangan internasional dari mulai Afrika, Australia Barat ke Laut Tiongkok Selatan dan Jepang serta sebaliknya. ALKI II meliputi jalur lintas perairan Laut Sulawesi, Selat Makassar, Selat Lombok dan Laut Lombok yang menghubungkan lalu lintas perairan dan perdagangan internasional dari Afrika ke Asia Tenggara dan Jepang serta dari Australia ke Singapura dan Tiongkok serta Jepang, begitu pula sebaliknya. ALKI III A meliputi jalur lintas perairan Samudera Pasifik, Selat Maluku dan Selat Seram (bagian timur Pulau Magole), Laut Banda (bagian barat Pulau Buru), Selat Ombai dan Laut Sawu yang menghubungkan jalur perairan dan perdagangan internasional Australia bagian barat ke Filipina dan Jepang, dan sebaliknya. ALKI III B meliputi jalur perairan dan perdagangan internasional, meliputi dari Autralia bagian timur, Selandia Baru dan Samudera Pasifik melalui Selat Torres, dan sebaliknya; atau melalui Selat Torres, Laut Arafuru, Laut Banda dan Laut Maluku. ALKI III C untuk pelayaran dari Samudera Pasifik melintasi Laut Maluku, Laut Seram, Laut Banda, Selat Ombai dan Laut Sawu ke Samudera Hindia. ALKI Cabang III E untuk pelayaran dari Samudera Hindia melintasi Laut Sawu, Selat Ombai, Laut Banda, Laut Seram dan Laut Maluku. 


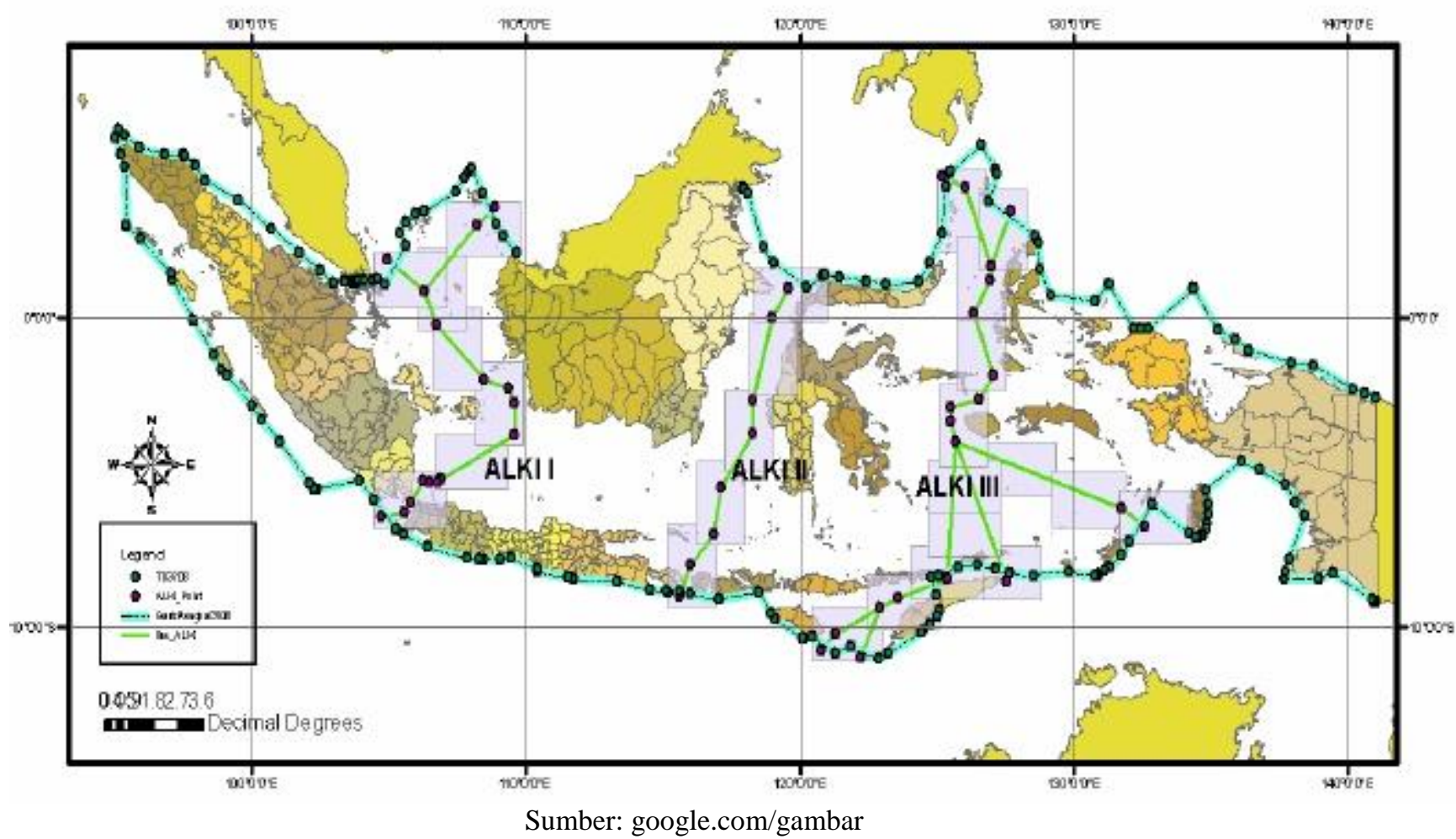

Dengan demikian, tujuan diciptakannya alur laut kepulauan di perairan teritorial atau di perairan kepulauan suatu negara ialah untuk menghubungkan antara satu bagian ZEE atau laut bebas ke bagian ZEE atau laut bebas lain. ALKI diundangkan dalam PP No. 37 Tahun 2002 dan diusulkan ke IMO sejak tahun 1998. Bagi Indonesia, penentuan ALKI memberikan konsekuensi pada pengendalian atau pengontrolan untuk keamanan dan keselamatan di ALKI. Pengendalian ALKI diartikan menegakkan kedaulatan Indonesia di daerah/wilayah perairan nasional, yang digunakan untuk lintas internasional. Pengendalian dan penjagaan yang dimaksud adalah keamanan negara, keselamatan negara dari bahaya ancaman baik yang datang dari dalam maupun dari luar, termasuk pelanggaran hukum.

Lintas alur kepulauan memiliki sejumlah larangan yang harus diperhatikan pengguna lintas kepulauan. Baik kapal ataupun pesawat udara tidak boleh memasuki pelabuhan dan lintas harus dilaksanakan secara langsung dari ZEE, laut bebas atau ke ZEE atau laut bebas lainnya; tidak boleh berhenti atau menunda pelayaran dan penerbangan. Dengan ditentukannya jalur ALKI, membuat negara Indonesia menjadi terbuka karena perairan dan ruang udara di atasnya harus terjamin keamanannya dari segala bentuk gangguan dan ancaman. Menurut Connie Rahakundini Bakrie, ALKI memberikan manfaat kepada Indonesia. Peradaban yang berhubungan dengan laut menjadi penghubung Eurasian Blue Belt, yang berperan dalam global logistic support system; khususnya SLOCS (Sea Lanes of Communications), COWOC (Consilidated Ocean Web of Communication) dan menjadi penghubung HASA (Highly Accessed Sea Areas) di mana ketiga lautan di Southeast dan South Pacific bertemu di dalamnya dengan muatan dry cargo maupun liquid cargo (Kompas.com. 2015).

Selat Malaka merupakan jalur yang terpendek lalu lintas barang dan suplai energi dari Timur Tengah ke Eropa, Afrika dan Asia Timur seperti Jepang, Tiongkok dan Korea. Ia mampu memendekkan jarak tempuh hingga kira-kira $2.000 \mathrm{~km}$, dibandingkan jika melalui Selat Sunda. Apabila terjadi gangguan di Selat Malaka, maka dilihat dari lamanya pelayaran 
dari Selat Malaka ke Selat Sunda atau Selat Lombok akan memerlukan tambahan waktu sampai tiga hari.

Mengingat posisi Indonesia menjadi penghubung antara dua benua, Asia dan Australia, serta penghubung dua lautan bebas, Pasifik dan India, maka ALKI memotong kesatuan wilayah perairan Indonesia dan alur laut kepulauan dapat digunakan sebagai laut bebas. Sehingga, ancaman dapat berupa illegal fishing; drug, human and guns trafficking; terorisme; piracy; global warming and climate changes; illegal migration; energy security chain; water and food security. Banyak tantangan yang dihadapi Indonesia dalam penetapan ALKI. Indonesia harus mampu menjawab tantangan itu; misalnya, bio-prospecting, climate change/sea level rise, volution of coastal and ocean economic; co-management antara pusat dan daerah serta stakeholders; integrated coastal and ocean management, large marine ecosystem, introduced marine pest, marine biotechnology, installations and structures, people smuggling/illegal migrants, piracy/maritim terrorism, place of refuge, pollution from land base activities, seabased minning (Djalal 2012, XV). Menurut Marsetio, Kepala Staf Angkatan Laut (Buntoro 2014, xv):

\begin{abstract}
"Barometer keamanan kawasan Asia Tenggara dapat dilihat dari kondisi keamanan Indonesia. Mengingat fakta bahwa 90\% perdagangan dunia melalui laut dan pusat perkembangan perokonomian berada di Asia, maka perairan di kawasan regional Asia Tenggara selalu dipandang penting bagi negara-negara di dunia sebagai kawasan perairan kompetensi bagi jalur komunikasi laut (Sea lanes of Communication/SLOC) dan Sea Lanes of Trade/SLOTD) yang vital bagi perdagangan internasional. Perdagangan di dan ke Asia/Asia Tenggara selalu menggunakan perairan Indonesia. Kondisi ini tentu saja dapat menimbulkan persoalan keamanan maritim."
\end{abstract}

Dalam menjawab tantangan tersebut, berbagai upaya semestinya dilakukan oleh pemerintah untuk membenahi regulasi-regulasi di bidang kelautan, meningkatkan teknik kelautan, politik kelautan, termasuk merancang dan menentukan ALKI. Pengendalian laut menurut Kresno Buntoro mengandung dua hal pokok (2012, 191): pertama, menjamin kelancaran dan keamanan terselenggaranya penggunaan dan pemanfaatan laut bagi kepentingan sendiri dan kawan. Kedua, mencegah penggunaan laut oleh pihak yang merugikan kepentingan sendiri. Pelaksanakan fungsi pengendalian laut didasarkan kepada sumber kekuatan laut yang menjadi komponen kekuatan pertahanan keamanan negara di laut, yang meliputi kekuatan militer maupun non-militer. Kewajiban semua elemen masyarakat untuk menjaga keamanan baik di darat maupun di laut seperti yang diamanatkan dalam UU No. 3 Tahun 2002 tentang Pertahanan Negara dan UU No. 34 Tahun 2004 tentang TNI dan Pemerintah untuk melakukan pembinaan sumber dan komponen pertahanan negara di laut.

Kepentingan negara maritim dan negara pengguna terhadap ALKI adalah bersumber pada keamanan dan kelancaran pelayaran di wilayah perairan. Masyarakat internasional mempunyai kepentingan di dua samudera yaitu Samudera Pasifik, Samudera Hindia dan di negara-negara di sekitar kedua benua dan di sekeliling samudera tersebut. Indonesia dalam komunitas internasional disebut juga jembatan kepentingan dua benua. Perairan Indonesia sangat penting atau vital bagi perairan internasional. Penetapan alur memberikan manfaat kepada Indonesia karena Indonesia dapat dengan gampang mengawasi dan mengontrol kapal dan pesawat udara asing yang melintasi perairan Indonesia. Selat Malaka dan perairan Asia Tenggara merupakan perairan yang strategis yang banyak dilalui oleh kapal dagang dan kapal yang mengadakan transit. Manfaat yang lain dengan ditentukannya alur laut ialah dapat mengembangkan industri dan jasa maritim di sepanjang alur laut kepulauan. Indonesia sudah waktunya menyiapkan pintu/pos penjagaan. 


\subsection{Ancaman Keselamatan dan Keamanan di ALKI}

Posisi geografis Indonesia yang sangat strategis menjadi barometer stabilitas keamanan di kawasan Asia dan Pasifik, khususnya di kawasan Asia Tenggara. Lebih dari $80 \%$ wilayah perairan masuk ke dalam wilayah yuridiksi Indonesia. Polemik yang berkembang dengan penetapan alur laut kepulauan menyebabkan adanya pandangan ALKI dianggap sebagai mengurangi kedaulatan Indonesia dan menimbulkan kewajiban dan beban bagi Indonesia. Sebab, Indonesia harus dapat memberikan jaminan keamanan di ALKI dan kemungkinan lain dapat mengundang keterlibatan tentara asing.

Keselamatan dan keamanan pelayaran internasional harus menjadi prioritas negara kepulauan sesuai dengan amanah pasal 53 ayat 10 Konvensi Hukum Laut Internasional 1982, bahwa negara kepulauan harus jelas menunjukkan sumbu-sumbu alur laut dan skema pemisah lalu lintas yang ditentukan atau ditetapkannya pada peta-peta yang harus diumumkan sebagaimana semestinya. Selain membuat sumbu-sumbu laut dan skema pemisah, Indonesia diwajibkan untuk menetapkan jalur pemisah lalu lintas laut/bagan pemisah lalu lintas laut (traffic separation scheme/TSS) di alur pelayaran khususnya di terusan/selat, misalnya alur pelayaran di Selat Singapura dan Selat Malaka. Penetapan TSS ini bertujuan untuk keselamatan pelayaran, pelindungan ke lautan dan untuk menghindari kecelakaan di laut, Dalam penentuan TSS Indonesia mengajukan pada IMO untuk mendapat persetujuan. Persetujuan dikeluarkan setelah melalui proses persidangan dari Maritime Safety Committee (MSC) dan diteliti oleh Sub-Navigation. Indonesia termasuk negara yang memiliki banyak selat. TSS ini kemudian dipasang di selat-selat yang dimiliki Indonesia seperti Selat Sunda, Selat Makassar, Selat Lombok dan lain-lain.

Upaya untuk membuat sumbu-sumbu, skema pemisah dan TSS yang dibuat di sepanjang alur laut navigasi dan kepulauan bertujuan untuk mencegah gangguan ancaman keselamatan pelayaran. Namun ancaman masih terus berlangsung; misalnya sengketa wilayah yang dapat menyebabkan instabilitas keamanan di negara-negara ASEAN. Lain lagi ancaman lingkungan di sekitar alur laut kepulauan yang disebabkan peningkatan lalu lintas pelayaran. Bahaya yang mengancam di sepanjang lintasan alur laut kepulauaan antara lain, yaitu: Pertama, meningkatnya volume perdagangan dunia. Kedua, adanya intervensi dari negara maritim besar untuk mengamankan jalur perdagangan. Perompakan dan terorisme mendorong negara maritim besar untuk ikut terlibat dalam pengamanan sea lanes of communication, misalnya dalam bentuk pengerahan kekuatan, mekanisme hukum internasional, mekanisme hukum regional, mekanisme hubungan regional dan bilateral. Ketiga, adanya aktivitas ilegal dalam bentuk kejahatan lintas negara (trans-national crime), berupa penyelundupan manusia, senjata ringan dan narkotika. Ratusan ribu pucuk senjata ringan (small arm and light weapons) diselundupkan di Asia Tenggara dan jalur peredarannya kebanyakan melalui laut. Dalam hal illegal migrants, setiap tahun ribuan orang dengan kapal melintasi perairan Indonesia untuk bermukim di negara lain. Ancaman yang lain dan cukup berbahaya yaitu perusakan lingkungan, eksploitasi sumber daya alam secara berlebihan, illegal fishing, unregulated and unreported fishing (IUU fishing) (Buntoro 2012, 189).

Masing-masing alur laut kepulauan mempunyai potensi ancaman keamanan. Bagi kapal dan pesawat asing yang melintasi Laut Tiongkok Selatan, Selat Karimata, Selat Sunda dan Laut Jawa (ALKI) gangguan keamanan bermacam-macam; antara lain: perlintasan dapat dimanfaatkan sebagai kegiatan dan manuver angkatan perang bagi negara-negara yang terlibat dalam konflik Laut Tiongkok Selatan dalam memperebutkan kepulauan Spratly dan Paracel seperti Tiongkok, Jepang, Filipina, Amerika Serikat dan lain-lain. Selain itu, kepadatan lalu lintas pelayaran Selat Malaka dan Selat Singapura di mana 45\% dari 75\% alur pelayaran perdagangan Asia Pasifik melintasi kedua selat tersebut. Selat Malaka dan Selat Singapura merupakan lintasan terpadat di dunia setelah Terusan Suez dan Terusan Panama. Terdapat 
ancaman keamanan dalam bentuk perampokan, perdagangan narkotika dan bahwa alur laut kepulauan ini dapat digunakan untuk menghindari pengawasan dan pengejaran aparat keamanan gabungan (Indonesia, Malaysia, dan Singapura). Kegiatan penyelundupan barang ilegal dan perdagangan manusia termasuk pencemaran lingkungan karena kecelakaan kapalkapal tanker dan pencurian ikan (illegal fishing) dan bajak laut marak juga terjadi di sepanjang ALKI I.

Sementara, untuk ALKI II yang melintasi Laut Sulawesi, Selat Makassar, Selat Lombok dan Laut Flores potensi ancamannya adalah konflik perbatasan Blok Ambalat dengan Malaysia-Indonesia yang sering dijadikan sebagai manuver angkatan perang dari Malaysia dan Indonesia. Illegal fishing (unregulated and unreported fishing/IUU) terorganisir yang merugikan secara ekonomi, sosial dan ekologi. Eksplotasi sumber daya alam, perdagangan manusia, narkotika. Terorisme sekarang ini menjadi ancaman yang sangat membahayakan di kawasan Laut Sulawesi-Selat Suluh. Ancaman radikalisme seperti ISIS, yang awalnya bersumber dari konflik internal di Filipina dengan gerakan separatis suku Maori di Mindanao, akan mempengaruhi keamanan di sekitar perbatasan langsung dengan Miangas . Laut Sulawesi - Selat Suluh perairan sekitar Indonesia yang berbatasan di bagian Timur Sabah Malaysia. Serangan terorisme di Marawi Filipina sangat mengkhawatirkan bagi negaranegara yang berbatasan. Pertemuan para Menteri Tingkat ASEAN telah menyetujui tugas dan rencana aksi 15 poin, di antaranya meningkatkan usaha dan kerja sama dalam menangani akar permasalahan dan kondisi ekstremisme; namun tidak terbatas pada kemiskinan, narkotika atau obat-obatan terlarang, kejahatan dan ketidakadilan sosial (Detik.com 2017). Laut Sulawesi juga menarik perhatian internasional karena aktivitas bajak lautnya yang tak hanya menggarong nelayan kecil, namun juga kapal-kapal kontainer raksasa.

Untuk ALKI III yang melintasi Samudera Pasifik, Laut Maluku, Laut Seram dan Laut Banda, potensi ancamannya hampir sama dengan ALKI I dan ALKI II: pengaruh dari lepasnya Timor Timur menjadi negara berdaulat (Timor Leste) terkait dengan blok migas di sebelah selatan Pulau Timor. Wilayah ALKI IIIA juga menjadi sarana pelarian kejahatan kemanusiaan atau kegiatan lain yang membahayakan keamanan. Selain itu, faktor-faktor gangguan keamanan internal dan eksternal seperti konflik internal gerakan separatisme Republik Maluku Selatan (RMS) di Maluku dan dan Gerakan Papua Merdeka (GPM) di Papua. Pengaruh politik luar negeri Australia yang mendukung Timor Leste dan Papua New Guinea. Ada pula ancaman perbatasan, penegakan hukum, kedaulatan di laut perikanan, wisata bahari, eksplorasi lepas pantai (off shore), transportasi laut, klaim wilayah dan pengelolaan sumber daya alam.

Melalui kerja sama bilateral dan multilateral penyelesaian ancaman keselamatan dan keamanan di laut dapat dilakukan. Untuk tingkat domestik, dengan membangun budaya maritim dan kerja sama antar-kementerian yang terkait. Menurut Laksamana Suhartono, ada tiga cara penyelesaian, yaitu: maritime awareness, confidence building measure, maritime security (Suhartono 2008, 3). Lebih lanjut disampaikan dalam menangani masalah keamanan laut, ada tiga hal mendasar yang harus diperhatikan, yaitu: framework dalam membangun wadah kerja sama, penghormatan terhadap negara pantai dan kapasitas nasional; seperti penguatan pemahaman dan implementasi dari Konvensi Hukum Laut Internasional dan hukum internasional lainnya mengenai perampokan bersenjata, pembajakan laut, terorisme dan proliferasi senjata pemusnah massal. Kerja sama bilateral dan multilateral di kawasan regional seperti ASEAN dan di kawasan Asia Pasifik perlu ditingkatkan. Untuk kawasan ASEAN perlu diintensifkan kerja sama. Indonesia telah menghasilkan kerja sama Malsindo Coordinated Patrol dengan Singapore, Malaysia, disusul Thailand, mengenai keamanan di sekitar Selat Malaka. Indonesia juga dapat menginisiasi kerja sama lainnya sehubungan dengan keamanan maritim. Ada baiknya hal ini menjadi agenda pembahasan Komunitas Masyarakat ASEAN pilar ketiga "politik dan keamanan". 
Pengamanan di Alur Laut Kepulauan Indonesia merupakan tugas TNI Angkatan Laut. Untuk peningkatan keamanan, dapat dilakukan melalui peningkatan personel dan peralatan yang dimiliki TNI AL, maupun koordinasi keamanan laut yang efektif di bawah Bakorkamla. ALKI I dan II merupakan perlintasan yang paling ramai dan rawan. Patroli kapal perang TNI AL beberapa kali mendeteksi kapal selam negara asing melintas di bawah laut pada beberapa titik ALKI. Langkah strategis yang diambil TNI AL di ALKI adalah memasang instalasi sonar di bawah laut untuk mendeteksi kapal selam negara lain yang melintasi titik perlintasan strategis. Lebih lanjut dikatakan Panglima Armada Indonesia kawasan barat (Pangarmabar) Laksamana Muda TNI Aan Kurnia, instalasi sonar bawah laut ini akan dipasang di Selat Sunda yang berada di antara Pulau Jawa dan Pulau Sumatera. Lokasi lain yang akan dipasangi alat ini adalah Selat Lombok yang diapit Pulau Bali dan Pulau Lombok (Defence Studies 2017). Pemasangan instalasi sonar ini berfungsi memagari selat-selat dan akan memantau secara terus-menerus alur lintas kepulauan selama 24 jam tanpa patroli TNI AL.

Peningkatan pertahanan kemananan di perlintasan ALKI I, II dan III juga dapat dilakukan dengan cara membangun pintu masuk dan pintu keluar, termasuk membangun pos penjagaan keluar dan masuk. Ada beberapa hal yang perlu dilakukan untuk itu: Pertama, meningkatan pertahanan-keamanan di sepanjang alur laut kepulauan mengingat tingginya potensi ancaman; baik yang berasal dari negara tetangga maupun kapal-kapal asing, terutama potensi ancaman keamanan nontradisional seperti terorisme, illegal fishing, bajak laut, perdagangan manusia dan lain-lain. Kedua, penerapan visi Pemerintahan Jokowi menjadikan Indonesia sebagai poros maritim dunia, di antaranya dengan cara mengubah pendekatan dari continental-based development menjadi maritime/sea-based development untuk menwujudkan pertumbuhan ekonomi dan pembangunan kawasan pesisir, pemberdayaan nelayan. Peningkatan ekonomi kelautan di kawasan pesisir tentu diharapkan akan berkorelasi positif dengan pengurangan gangguan keamanan di laut. Ketiga, perlunya kajian komprehensif mengenai alur laut kepulauan, baik dari aspek pertahanan-keamanan, ekonomi, dan sosial-budaya. Dengan demikian hasil yang diharapkan ada pemetaan yang jelas mengenai potensi ancaman dan potensi ekonomi yang bisa dikembangkan masyarakat pesisir, agar cita-cita maritime/sea-based development dapat terwujud. Keempat, menjadikan Indonesia sebagai poros maritim dunia yang berkekuatan besar dan bertitik tumpu di dua samudera besar. Peran dari para ahli dari berbagai displin ilmu sangat diperlukan untuk melakukan pengkajian secara komprehensif dan berkala mengenai alur laut kepulauan, baik dari aspek pertahanan-keamanan, ekonomi, dan sosial-budaya sehingga dapat dibuat pemetaan yang jelas mengenai potensi ancaman dan potensi ekonomi yang bisa dikembangkan masyarakat pesisir, terutama untuk mendukung maritime/sea-based development. Dengan demikian, cita-cita membangun Indonesia sebagai poros maritim dunia sebagai suatu kekuatan besar pada titik tumpu di dua samudera dapat terwujud.

\section{Kesimpulan}

Sejak tahun 2002 melalui Peraturan Pemerintah No. 37 Tahun 2002 Indonesia sudah menentukan ada 3 (tiga) ALKI di wilayah perairan Indonesia yang menjadi alur lintas bagi kapal-kapal asing dan pesawat terbang asing yang terbang melintasi wilayah udara Indonesia. Ketentuan ini mengatur hak dan kewajiban negara kepulauan dan pengguna alur laut kepulauan, yaitu setiap kapal asing dan pesawat udara asing dapat dengan bebas melaksanakan hak lintas alur laut kepulauan melalui bagian tertentu laut teritorial dan perairan kepulauan Indonesia dengan rute yang telah ditentukan, tidak boleh lagi bercabang dalam bernavigasi atau menyisir area ke daratan sesuai rute-rute pelayaran yang terdahulu. Kapal dan pesawat udara internasional tersebut wajib mematuhi jalur yang sudah ditetapkan. Sehingga dalam melaksanakan lintas alur laut kepulauan setiap kapal-kapal asing 
baik kapal niaga, kapal tanker dan kapal perang dan pesawat terbang niaga dan pesawat militer asing harus memenuhi syarat-syarat yang ditentukan negara kepulauan agar setiap pengguna lintasan dapat berlayar dengan selamat sampai ketempat tujuan. Bagi kapal-kapal militer dan pesawat udara militer harus ada notafikasi baru dapat berlayar memasuki alur laut kepulauan.

Akan tetapi, masih banyak masalah dalam penerapan pasal 53 ayat 3 Konvensi Hukum Laut Internasional 1982 antara lain: Pertama, menyangkut monitoring dan controlling terhadap kapal dan pesawat udara asing yang melintasi wilayah Indonesia. Kedua, penafsiran terhadap implementasi dari monitoring dan kontrol terhadap kapal-kapal militer dan pesawat militer asing pengguna alur lintas kepulauan laut dan udara; sejauh mana Indonesia dapat bertindak jika terjadi kegiatan latihan perang atau kegiatan mata-mata di sepanjang alur laut kepulauan, termasuk pengaturan ketinggian pesawat udara yang terbang melintasi alur laut kepulauan. Sebagai contoh, pelayaran armada Amerika Serikat yang melintasi Laut Jawa dari arah Singapura, Australia dan penerbangan pesawat-pesawat F-18 dan armada lainnya di perairan Bawean pada tanggal 3 Juli 2003. Menurut pemerintah Indonesia, dalam pelayaran dan penerbangan telah terdapat pelanggaran hukum internasional; sedangkan Amerika Serikat berpendapat bahwa Indonesia belum menentukan alur laut kepulauan secara penuh, maka masih ada hak lintas alur laut kepulauan di rute-rute normal untuk pelayaran internasional.

Implikasi dari penetapan alur laut kepulauan berdampak pada aspek ekonomi, lingkungan, sosial, hukum, politik dan keamanan. Berbagai persoalan dan masalah yang timbul dengan penetapan alur laut dan harus segera ditindaklanjuti dengan langkah-langkah perbaikan baik dari aspek hukum nasional, hukum internasional dan hal-hal yang bersifat teknis kelautan. Perlu diadakan perundingan dengan negara-negara di kawasan Asia Tenggara seperti Singapura, Malaysia dan Filipina dan dengan negara-negara besar pengguna laut.

Selain masalah-masalah yang terdapat di alur lintas kepulauan yang menghubungkan utara-selatan, ada masalah lain menyangkut penetapan alur lintas timur-barat dari Selat Malaka, Laut Jawa dan Laut Arafura yang disebut dengan partial designation. Indonesia sudah berjanji pada tahun 1989 pada saat pertemuan MSC yang ke 72 (Maritime Safety Committee) agar membuka alur laut kepulauan Indonesia rute timur-barat (ALKI IV). Amerika Serikat, Rusia, Australia dan negara lainnya yang berkepentingan terhadap ALKI IV masih menunggu realisasi dari Indonesia. Sampai saat ini Indonesia belum bersedia membuka alur lintas timur dan barat karena menyangkut pertahanan-keamanan Indonesia. Mengingat letak pusat pemerintahan di Jakarta sebagai ibu kota Indonesia berada tepat di pesisir Laut Jawa, yang sangat rawan terhadap ancaman dan gangguan serangan dari laut maupun udara. 


\section{DAFTAR PUSTAKA}

\section{Buku}

Anwar, Chairul. 1995. Hukum Internasional, Horizon Baru Hukum Laut Internasional Konvensi Hukum Laut. Jakarta: Djambatan.

Arsana, I Made Andi. 2007. Batas Maritim Antar Negara, Sebuah Tinjauan Teknis dan Yuridis. Yogyakarta: Gadjah Mada University Press.

Dan, Syamsumar. 2010. Politik Kelautan. Jakarta: Bumi Aksara.

Danusaputra, Munadjat. 1981. The Marine Enviroment of South Asia. Bandung: Binacipta.

Djalal, Hasyim. 1979. Perjuangan Indonesia di Bidang Hukum Laut. Bandung: Binacipta.

Jessup, Philip C. 1959. The United Nations Conference on the Law of the Sea. Columbia Review.

Kresno, Buntoro. 2012. Alur Laut Kepulauan Indonesia (ALKI), Prospek dan Kendala. Jakarta: Sekolah Staf dan Komando TNI AL (SESKOAL).

-------------. 2014. Lintas Navigasi di Nusantara Indonesia. Jakarta: PT Raja Grafindo Persada.

Kusumaatmadja, Mochtar, 1978. Bunga Rampai Hukum Laut. Bandung: Binacipta. , 1982, Hukum Laut Internasional, Bandung, Binacipta

Mauna, Boer. 2001. Hukum Laut Internasional: Pengertian, Peranan dan Fungsi dalam Era Globalisasi. Jakarta: Alumni.

Leifer, Michael. 1978. International Straits of The Aworld: Malacca, Singapore and Indonesia, International Straits of the World.

Presscott,Victor dan Clive Schofield. 2005. The Maritime Political Boundaries of The World. Suprianto, M. 2014. Tentang Ilmu Pertahanan. Jakarta: Yayasan Obor Indonesia.

Syafrinaldi, H. 2009. Hukum Laut Internasional. Riau: UIR Press.

\section{Jurnal/Artikel/Makalah}

Sinaga, Christina Lidya. 2011. "Menilik Alur Laut Kepulauan II.” Pusat Penelitian Politik. Diakses pada 14 Mei 2017. http://www.politik.lipi.go.id/kolom/kolom-1/politik-internasional/413-menilik-alurlaut-kepulauan-indonesia-ii.

Irmah, Rustam. 2015. "Tantangan ALKI dalam Mewujudkan Cita-Cita Indonesia Sebagai Poros Maritim Dunia.” Indonesia Perspective 1 (1, Januari-Juni):1-12.

\section{Internet}

BBC. “Mewujudkan Mimpi RI Jadi Poros Maritim Dunia.” Diakses 12 Maret 2017. https://www.cnnindonesia.com/internasional/20141022124012-1127389/mewujudkan mimpi-ri-jadi-poros-maritim-dunia/.

Kata Data News and Research. "Awasi Kapal Selam Asing Pemerintah.” Diakses 15 Agustus 2017.

http://defense-studies.blogspot.co.id/2017/08/awasi-kapal-selam-asingpemerintah.html.

Tempo. "Pertemuan Tiga Negara Mengantisipasi ISIS di Marawi."

Diakses 10 Juli 2017. https://m.tempo.co/read/news/2017/06/24/118887080/antisipasi-isis-di-marawiindonesia-gelar-pertemuan-3-negara. 
Detik.com. "Indonesia-Malaysia, Filipina Sepakat 15 Poin Kontra Terorisme.”

Diakses 5 Agustus 2017.

https://news.detik.com/berita/d-3539922/indonesia-malaysia-dan-filipina-sepakati-15poin-kontra-terorisme.

Kompas.com http://nasional.kompas.com/read/2014/10/09/20525171/

Pengamat.Butuh.Anggaran.Pertahanan.yang.Besar.Jadikan.Indonesia.Poros.Maritim

\section{Perundang-undangan/Konvensi}

UU No. 6 Tahun 1996 Tentang Perairan Indonesia.

UU No. 17 Tahun 1985 Tentang Pengesahan United Nations Convention on The Law of The Sea (Konvensi Perserikatan Bangsa-Bangsa Tentang Hukum Laut).

UU No. 6 Tahun 1996 Tentang Perairan Indonesia.

Peraturan Pemerintah No. 37 Tahun 2002 tentang Peraturan Pemerintah No. 37 Tahun 2002 tentang Hak dan Kewajiban Kapal dan Pesawat Udara Asing.

Peraturan Pemerintah No. 36 Tahun 2002 Tentang Hak dan Kewajiban Kapal Asing dalam Melaksanakan Lintas Damai Melalui Perairan Indonesia.

Peraturan Pemerintah No. 37 Tahun 2002 Tentang Hak dan Kewajiban Kapal dan Pesawat Udara Asing dalam Melaksanakan Lintas Damai Melalui Perairan Indonesia.

Konvensi Perserikatan Bangsa-Bangsa Tentang Hukum Laut Tahun 1982. 